\title{
MANAJEMEN PEMBELAJARAN BAHASA INGGRIS \\ PADA SMAN 3 BATUSANGKAR
}

\author{
Ade Alfa Pramudia \\ Alumni Program Studi Manajemen Pendidikan Islam \\ Program Pascasarjana IAIN Batusangkar \\ e-mail: dealfa89@gmail.com
}

13062

\begin{abstract}
The problem of this research was that the English instructional management at SMAN 3 Batusangkar has unrevealed yet. The purpose of this research was to describe the English instructional management at SMAN3 Batusangkar. The researcher used case study of qualitative research. In analyzing the data, researcher used Miles and Huberman steps, they are data reduction, data display, and conclusion drawing/verification. In checking data trustworthyness, the researcher used data triangualtion technique. Based on the result of this study, it can be concluded that concluded that English instructional management at $S M A N 3$ Batusangkar is in compliance as mandated in the regulation. It can be seen through intracurricular aspects, such as in planning, using method, conducting learning activities, and doing evaluation, and at extracurricular aspects, such as motivating student, rebuilding emotional relationship, practicing English, and channeling the students' English talent, in spite of weaknesses in implementing innovative learning methodologies by the teachers.
\end{abstract}

Keywords: Management, Instruction, English

\section{PENDAHULUAN}

SMAN 3 Batusangkar berdiri atas kebijakan pemerintah daerah Tanah Datar untuk mengadakan sebuah sekolah yang unggul dari segi program pendidikannya. Siswa yang diterima di sekolah ini merupakan siswa yang memang memiliki nilai yang tinggi dan lulus dalam beberapa tahapan seleksi yang bisa dikatakan cukup ketat. Hal ini dimaksudkan agar siswa yang belajar di sekolah ini mampu mengikuti pembelajaran kompetitif, karena umumnya mereka memiliki prestasi akademik yang tinggi dari sekolah asal mereka. Sehingga pada akhirnya siswa-siswa yang lulus dari lembaga pendidikan ini memiliki daya saing tinggi untuk dapat diterima di berbagai perguruan tinggi favorit di tanah air.

Manajemen pendidikan yang diterapkan oleh manajerial sekolah agaknya berhasil mewujudkan tujuan berdirinya SMAN 3 Batusangkar ini, yaitu keunggulan dalam segi prestasi akademik maupun non akademik. Hal ini bisa dibuktikan dengan beragam 
prestasi yang ditorehkan oleh putra-putri terbaik Tanah Datar ini baik di tingkat provinsi maupun nasional. Misalnya pada tahun 2016 salah seorang siswa SMAN 3 Batusangkar berhasil meraih tiga besar UN Provinsi SUMBAR dan salah seorang putra terbaik Luhak Nan Tuo ini mampu mengharumkan nama SUMBAR di kancah nasional dalam upacara pengibaran bendera pusaka pada 17 Agustus 2016, peserta forum anak nasional, pertukaran pelajar nasional, dan juara 1 pada perlombaan Tata Ruang tingkat nasional.

Di samping itu, siswa-siswi SMAN 3 Batusangkar juga memiliki berbagai prestasi akademik lainnya, pada 2013 salah satu peserta UN mampu meriah nilai 10 (sepuluh) untuk mata pelajaran matematika. Pada 2014 juga salah seorang siswi berhasil memperoleh nilai 10 (sepuluh) untuk mata pelajaran bahasa Inggris. Dan masih banyak prestasi yang diraih oleh SMAN 3 Batusangkar dalam berbagai perlombaan baik ditingkat lokal, regional, dan nasional. Bukan hanya siswa saja yang menorehkan berbagai prestasi, namun guru juga ternyata ikut andil dalam mengharumkan nama lembaga unggulan ini, misalnya peraih prediket 1 (satu) guru terbaik nasional tahun 2012, peserta OSN guru fisika nasional, dan sebagainya.

Dari berbagai kondisi dan prestasi yang peneliti paparkan di atas, peneliti menemukan hal menonjol pada mata pelajaran bahasa Inggris. Di samping prestasi akademik yang baik, SMAN 3 Batusangkar juga memiliki prestasi dalam mengikuti berbagai kompetisi atau perlombaan bahasa Inggris, khususnya pada lomba debat dan sering mendapatkan berbagai prestasi dari keikutsertaan tersebut.

Penasaran dengan rahasia guru sehingga siswa-siswa di sekolah ini mampu meraih berbagai prestasi seperti di atas, peneliti menanyakan apakah siswa-siswa di sekolah tersebut memiliki pelajaran tambahan bahasa Inggris di luar sekolah, ternyata jawaban yang mengherankan peneliti muncul dari ungkapan guru yang menyangkal adanya siswa yang memiliki pelajaran tambahan (les) di luar sekolah. Dalam kesempatan yang sama, informan yang peneliti wawancarai menceritakan kondisi mata pelajaran bahasa Inggris di sekolah tersebut. Guru yang bertugas mengajar bahasa Inggris berjumlah 2 (dua) orang guru.

Hal lain yang peneliti dapatkan dari hasil wawancara tersebut ialah, penyebab tingginya hasil proses pembelajaran dan di SMAN 3 Batusangkar ini pihak sekolah yang bersangkutan berkaitan dengan proses pembelajaran itu sendiri. Tidak jelas pada bagianmana, namun bisa peneliti simpulkan bahwa berkaitan dengan penyelenggaraan pembelajaran dan manajemen pembelajaran yang diterapkan guru dalam proses pembelajaran, misalnya seperti kiat mensukseskan pembelajaran, metode pembelajaran, persiapan pembelajaran, komunikasi, perencanaan pembelajaran, dan pelakasaan pembelajaran. 


\section{LANDASAN TEORITIK}

\section{Pembelajaran Bahasa Inggris}

Pembelajaran adalah proses intergrasi siswa dan guru dalam komunikasi dan interaksi dalam ruang kelas dengan bahasan teori dan nilai untuk tujuan tercapainya tujuan yang telah ditetapkan sebelumnya. Pembelajaran banyak didefenisikan oleh para ahli Berikut beberapa diantaranya;

a. Syaiful Sagala, pembelajaran adalah membelajarkan siswa menggunakan azas-azas pendidikan maupun teori belajar yang merupakan penentu utama keberhasilan pendidikan, dalam pada itu ia menambahkan bahwa pembelajaran merupakan proses komunikasi dua arah. Guru mengajar sebagai tenaga pendidik dan belajar yang dilakukan oleh peserta didik. (Ramayulis, 2002: 336)

b. Oemar Hamalik mengemukakan bahwa pembelajaran adalah suatu kombinasi yang tersusun meliputi unsurunsur manusiawi, material fasilitas, perlengkapan dan prosedur yang saling mempengaruhi proses pencapaian pembelajaran. (Ramayulis, 2002: 336)

c. Corey, menyatakan bahwa pembelajaran adalah suatu proses di mana lingkungan seseorang secara disengaja dikelola untuk memungkinkan ia turut serta dalam tingkah laku dalam kondisi khusus atau menghasilkan respon terhadap situasi tertentu. (Ramayulis, 2002: 336)
Dari beberapa teori di atas bisa disimpulkan bahwa pembeljaran merupakn proses interksi dua arah antara guru dan siswa dimana terdapat materi yang dibahas dan tujuan yang harus dicapai dengan aturanaturan tertentu, yang dilakukan dengan mempertimbangkan aspek manusiawi.

\section{Bahasa Inggris dalam kurikulum 2013}

\section{a. Posisi Bahasa Inggris}

Eksistensi mata pelajaran bahasa Inggris dalam kurikulum pendidikan di Indonesia bisa dilihat dari struktur kurikulum itu sendiri. Berikut beban belajar di SMA/ SMK/MA/MAK masing-masing untuk kelas $\mathrm{X} 42$, dan 44 jam per minggu untuk kelas XI dan XII. Struktur Kurikulum SMA/SMK/ MA/MAK adalah sebagai berikut:

Tabel. 1: Struktur Kurikulum SMA/SMK/MA/MAK

\begin{tabular}{|c|c|c|c|c|}
\hline \multirow{2}{*}{\multicolumn{2}{|c|}{ MATA PELAJARAN }} & \multicolumn{3}{|c|}{\begin{tabular}{|c|} 
ALOKASI \\
WAKTU \\
BELAJAR \\
PER MINGGU \\
\end{tabular}} \\
\hline & & $\mathbf{X}$ & XI & XII \\
\hline \multicolumn{5}{|c|}{ Kelompok A (Wajib) } \\
\hline 1. & Pendidikan Agama dan Budi Pekerti & 3 & 3 & 3 \\
\hline 2. & $\begin{array}{l}\text { Pendidikan Pancasila dan } \\
\text { Kewarganegaraan }\end{array}$ & 2 & 2 & 2 \\
\hline 3. & Pendidikan Agama Islam & 4 & 4 & 4 \\
\hline 4. & Matematika & 4 & 4 & 4 \\
\hline 5. & Sejarah Indonesia & 2 & 2 & 2 \\
\hline 6. & Bahasa Inggris & 2 & 2 & 2 \\
\hline \multicolumn{5}{|c|}{ Kelompok B (Wajib) } \\
\hline 7. & Seni Budaya & 2 & 2 & 2 \\
\hline 8. & $\begin{array}{l}\text { Pendidikan Jasmani, Olah Raga, dan } \\
\text { Kesehatan }\end{array}$ & 3 & 3 & 3 \\
\hline & Prakarya dan Kewirausahaan & 2 & 2 & 2 \\
\hline & $\begin{array}{l}\text { nlah Jam Pelajaran Kelompok A dan B } \\
\text { minggu }\end{array}$ & 24 & 24 & 24 \\
\hline \multicolumn{5}{|c|}{ Kelompok C (Peminatan) } \\
\hline & $\begin{array}{l}\text { ta Pelajaran Peminatan Akademik } \\
\text { MA/MA) }\end{array}$ & 18 & 20 & 20 \\
\hline & $\begin{array}{l}\text { nlah Jam Pelajaran yang Harus } \\
\text { tempuh per Minggu }\end{array}$ & 42 & 44 & 44 \\
\hline
\end{tabular}

Sumber: Permendikbud No. 65 Tahun 2013 
Dari tabel di atas disimpulkan mata pelajaran bahasa Inggris terdapat dalam kurikulum pendidikan nasional Indonesia. Dengan demikian, ini merupakan suatu keharusan bagi seluruh lembaga pendidikan termasuk jenjang SMP untuk mengadakan pembelajaran bahasa Inggris sebagai mata pelajaran wajib.

\section{b. Tujuan Mata Pelajaran Bahasa Inggris}

Menurut Direktorat Pembinaan SMP (2012) Mata Pelajaran Bahasa Inggris bertujuan agar peserta didik memiliki kemampuan sebagai berikut:

1) Mengembangkan kompetensi berkomunikasi dalam bentuk lisan dan tulis untuk mencapai tingkat literasi performative dan functional;

2) Memiliki kesadaran tentang hakikat dan pentingnya bahasa Inggris untuk meningkatkan daya saing bangsa dalam masyarakat global;

3) Mengembangkan pemahaman peserta didik tentang keterkaitan antara bahasa dengan budaya

\section{Guru Bahasa Inggris}

Permendiknas No. 16 tahun 2007 mensyaratkan guru harus memiliki kualifikasi akademik pendidikan minimum Diploma Empat (D-IV) atau Sarjana (S1) Program Studi yang sesuai dengan mata pelajaran yang diajarkan/diampu, dan diperoleh dari program studi yang terakreditasi. Dalam Permendiknas tersebut juga dijabarkan penjelasan tentang kompetensi tenaga pendidik mata pelajaran. Dalam hal ini termasuk juga didalamnya kompetensi tenaga pendidik pada mata pelajaran bahasa Inggris. Dalam Permendikbud No. 16 Tahun 2007 juga tersirat kompetensi yang harus dimiliki oleh seorang guru bahasa Inggris. Dalam hal ini adalah kompetensi profesional, berikut isi peraturan tersebut; Kompetensi Guru mata pelajaran Bahasa Asing. Kompetensi Guru Bahasa Inggris pada SD/MI, SMP/MTs, dan SMA/MA, SMK/MAK

- Memiliki pengetahuan tentang berbagai aspek kebahasaan dalam bahasa Inggris (linguistik, wacana, sosiolinguistik, dan strategis).

- Menguasai bahasa Inggris lisan dan tulis, reseptif dan produktif dalam segala aspek komunikatifnya (linguistik, wacana, sosiolinguistik, dan strategis).

Sebuah kesepakatan bahwa seorang guru merupakan tenaga profesional dimana guru diberikan kepercayaan oleh masyarakat dan lembaga untuk mendidik siswa. Hasil bergantung pada profesionalitas seorang guru, tercapai tidaknya tujuan pembelajaran salah satunya tergantung guru tersebut. Hal ini berdasarkan hadis Nabi yang penulis kutip dari Fadlillah (2014);

Terjemahannya:

"Apabila suatu amanah disia-siakan, maka tunggulah saat kehancurannya. (Abu Hurairah) bertanya: bagaimana meletakkan amanah itu ya Rasulullah? Beliau menjawab; apa bila suatu perkara diserahkan bukan pada 
ablinya, maka tunggulah saat kehancurannya"

(HR. Bukhari)

Kegagalan merupakan konsekuensi yang harus diterima apabila suatu bidang diserahkan bukan pada ahlinya, laksana membangun sebuah rumah yang dikerjakan oleh seorang pengembala yang secara logika bukan merupakan pekerjaan atau keahliannya. Maka hasilmnya tentu tidak semaksimal bila dikerjakan oleh seorang tukang bangunan.

\section{Manajemen Pembelajaran}

Menurut George R Terry dalam Manulang (1976: 6), manajemen ialah: suatu proses tertentu, terdiri dari planning, organizing, actuating, controlling dengan menggunakan dengan menggunakan seni dan ilmu pengetahuan untuk setiap fungsi itu dan merupakan petunjuk dalam mencapai tujuan yang telah di tetapkan terlebih dahulu.

Manajemen pembelajaran didefinisikan oleh Mulyasa (2002: 39) sebagai usaha mengelola (to manage) lingkungan belajar dengan sengaja agar seseorang belajar berprilaku tertentu dalam kondisi tertentu. Jadi manajemen pembelajaran adalah proses yang di dalamnya terdapat interaksi antara guru dengan siswa dan komunikasi timbal balik yang berlangsung dalam situasi edukatif untuk mencapai tujuan belajar. Substansi-substansi pembelajaran terdiri dari guru, murid dan kurikulum yang menjadi acuan dalam proses pembelajaran tersebut.
Dalam satu kesatuan proses pembelajaran, terdapat komponenkomponen yang membangunnya. Dalam hal manajemen biasa dikenal dengan istilah fungsi-fungsi manajemen. Tercapai atau tidaknya sebuah tujuan sangat bergantung kepada proses yang membentuknya, upaya yang dilakukan oleh sumber daya yang ada di dalamnya, bila tugas dan fungsi sumber daya berjalan semestinya, maka bisa diasumsikan bahwa keberhasilan akan tercapai. Dalam mensukseskan proses pembelajaran, Davies (1991) mengemukakan tiga tahapan dalam sebuah proses pengelolaan pembelajaran yang baik yaitu perencanaan pembelajaran, pengorganisasian pembelajaran, dan kontrol terhadap pembelajaran.

\section{METODOLOGI PENELITIAN}

Jenis penelitian ini adalah penelitian studi kasus. Mulyana dalam Hanafi (2011: 178) menyatakan penelitian studi kasus adalah uraian dan penjelasan komprehensif mengenai berbagai aspek seorang individu, suatu kelompok, suatu organisasi, suatu program kegiatan, dan suatu situasi sosial. Penelitian ini dilakukan di SMAN 3 Batusangkar Kab. Tanah Datar, dan Peneliti menyelesaikan penelitian ini dalam waktu lebih kurang 4 (Empat) bulan. Teknik pemilihan sumber data menggunakan purpossive sampling, menurut Sugiyono (2011: 85) purposive sampling adalah dimana dalam pemilihan sumber data peneliti mengetahui dan menentukan dengan 
pertimbangan-pertimbangan tertentu. Dalam hal ini yang menjadi informan dalam penelitian ini adalah guru bahasa Inggris dan siswa di lingkungan SMAN 3 Batusangkar.

Dalam penelitian kualitatif, instrumen utama penelitian adalah peneliti sendiri. Artinya peneliti dalam mendapatkan data lebih banyak bergantung pada diri sendiri. Dengan kata lain, peneliti adalah instrument utama penelitian. Sedangkan dalam peleksanaannya, peneliti menggunakan beberapa alat pendukung berupa: perekam suara, perekam video, dan kamera. Untuk mendukung instrumen penelitian di atas, peneliti menggunakan hal berikut dalam proses pengumpulan data, yaitu: pedoman observasi, panduan wawancara, dan studi dokumentasi.

Dalam analisis data peneliti mengikuti pendekatan Miles dan Huberman, yaitu Data reduction, data display, dan conclusion drawing/verification. Untuk menentukan keabsahan data yang peneliti peroleh, peneliti menggunakan teknik triangulasi data (data triangulation). Dalam hal ini Peneliti melakukan triangulasi data pada sumber yaitu peneliti menggabungkan data yang peneliti peroleh dari informan yang satu ke yang lain, tekni yaitu membandingkan data yang peneliti peroleh dari informaninforman dengan dokumen terkait yang berhasil peneliti kumpulkan, dan waktu yaitu melihat kecocokan informasi yang peneliti peroleh dari sudut waktu yang berbeda.

\section{TEMUAN}

Dari penelitian yang dilakukan, penulis menemukan bahwa manajemen pembelajaran bahasa Inggris pada SMAN 3 Batusangkar terbagi kepada dua aspek, yaitu:

1. Aspek intrakurikuler

Pada aspek ini terdapat perencanaan pembelajaran, pemilihan metode pembelajaran, pelaksanaan pembelajaran, dan evaluasi proses pembelajaran.

2. Aspek ekstrakurikuler

Pada aspek ini terdapat kegiatan memotiavsi siswa, membangun hubungan emosional yang baik dengan siswa, pelatihan bahasa Inggris melalui kegiatan Homestay dan kunjungan ke Kampung Inggris Pare, dan menyalurkan bakat bahasa Inggris siswa melalui kegiatan English Club dan Morning News.

\section{PEMBAHASAN}

Davies (1991) mengemukakan tiga tahapan dalam sebuah proses pengelolaan (manajemen) pembelajaran yang baik yaitu perencanaan pembelajaran, pengorganisasian pembelajaran, dan kontrol terhadap pembelajaranManajemen pembelajaran seperti yang dikemukakan oleh Ferbriani Utami (2013) adalah sebagai suatu proses yang meliputi perencanaan, pengorganisasian, pelaksanaan, dan evaluasi pengajaran, dalam rangka mencapai tujuan pembelajaran. Pengelolaan pembelajaran bahasa 
Inggris dilakukan oleh para guru melalui merencanakan, memimpin para siswanya dan menunjukan arah, mengendalikan dan mengevaluasi kegiatan pembelajaran.

Senada dengan referensi di atas, Manajemen pembelajaran di SMAN 3 Batusangkar dimulai dengan proses perencanaan yang dilakukan oleh guru. Langkah Perencanaan yang dilakukan oleh guru yaitu dengan merujuk kepada peraturan yang ada. Dalam kurikulum 2013 silabus pembelajaran bahasa Inggris sudah didisain secara sentral oleh pemerintah yang digunakan guru sebagai rujukan untuk melakukan perencanaan dan penyusunan RPP. Tugas guru dalam merencanakan ini yaitu menurunkan materi yang ada dalam silabus kemudian mengkonstruksinya kedalam bentuk RRP. Dalam RPP terdapat langkah-langkah yang akan dilakukan guru dalam proses pembelajaran, materi yang akan diajarkan, metode yang akan digunakan, media yang dipilih guna mempermudah guru dalam menyampaikan materi pembelajaran, dan pedoman penilaian yang akan digunakan oleh guru untuk mengukur keberhasilan proses pemebelajaran. Secara keseluruhan hal tersebut sesuai dengan fakta yang penulsi temukan di lapangan dan dikuatkan dengan dokumen yang peneliti peroleh dari informan penelitian ini.

Tahapan kedua dalam manajemen pembelajaran bahasa Inggris yang dilakukan oleh guru bahasa Inggris di SMAN 3 Batusangkar ialah pemilihan metode.
Metode pembelajaran yang digunakan oleh guru bahasa Inggris di SMAN 3 Batusangkar cukup bervariasi. Metode tersebut ialah communicative approach, contextual teaching learning, three phase stage, dan metode konvensional (ceramah). Metode tersebut digunakan oleh guru bahasa Inggris di SMAN 3 Batusangkar secara permanen atau berkelanjutan, hal ini disebabkan metode tersebut dipandang cukup efektif oleh guru dalam mempermudah mereka dalam menyampaikan materi pembelajaran. Sehingga mata pelajaran bahasa Inggris mampu menjadi salah satu mata pelajaran yang unggul, hal ini terbukti dengan pencapaian nilai bahasa Inggris yang tinggi di lingkungan kabupaten Tanah Datar dan prestasi-prestasi yang berkaitan dengan bahasa Inggris yang sudah cukup banyak diraih oleh SMAN 3 Batusangkar baik tatanan lokal, regional, dan nasional.

Tahap pelaksanaan pembelajaran bahasa Inggris di SMAN 3 Batusangkar mengacu kepada perencanaan yang telah dirancang sebelumnya oleh guru bahasa Inggris dengan menerapkan langkah-langkah, metode, dan media yang telah dipilih oleh guru tersebut. Dalam pelaksanaannya guru sangat terbantu dengan ketersediaan fasilitas yang telah disediakan oleh sekolah, fasilitas tersebut berupa LCD/proyektor, Loudspeaker, dan buku-buku sebagai sumber belajar bagi guru dan siswa.

Tahapan akhir dalam manajemen pembelajaran adalah evaluasi. Guru bahasa 
Inggris di SMAN 3 Batusangkar melakukan evaluasi terhadap proses pemebelajaran. Hal ini bukan hanya sekedar sebuah tugas yang dibebankan oleh kurikulum, lebih dari itu evalausi dipandang sangat penting dalam sebuah proses pembelajaran oleh guru di SMAN 3 Batusangkar. Hal ini dibuktikan dengan komitmen sekolah dan guru yang menyiapkan fasilitas yang digunakan untuk kegiatan evaluasi berupa alat scanner yang dimanfaatkan oleh guru dalam melihat sejauh mana tujuan pembelajaran berhasil dicapai. Fakta lain yang peneliti temukan terkait evaluasi ialah guru memiliki blanko penilaian siswa untuk beberapa aspek yang dinilai, seperti sikap, pengetahuan, dan keterampilan. Dalam tahapan evaluasi, manajerial SMAN 3 Batusnagkar memvisualisasikan upaya sinerginitas antara lembaga dan orang tua, hal ini terlihat dari kebijakan yang mengharuskan orang tua secara langsung menerima hasil ulangan harian dan ujian yang diikuti oleh siswa.

Peneliti mengasumsikan manajemen pembelajaran di SMAN 3 Batusangkar sangat baik dan berjalan secara efektif. Tentu asumsi peneliti dikuatkan oleh bukti-bukti berupa prestasi yang diraih oleh sekolah khususnya pada mata pelajaran bahasa Inggris. Di samping itu suatu fakta yang kuat menjadi alasan bagi peneliti mengasumsikan bahwa manajemen pembelajran bahasa Inggris di SMAN 3 Batusangkar sangat biak yaitu salah seorang guru yang merupakan informan penelitian ini adalah peraih juara
1 pada pemilihan guru teladan tingkat nasional tahun 2012.

Aouta Ghania (2013:33) mengemukakan bahwa salah satu faktor untuk mensukseskan pembelajaran bahasa Inggris ialah motivation (motivasi), ia mengklasifikasikan motivasi ini merupakan faktor eksternal. Dalam hal ini guru bahasa Inggris telah memberikan motivasi kepada siswa dalam pembelajaran bahasa Inggris dengan menciptakan budaya bahasa Inggris di SMAN 3 Batusangkar. Bisa disimpulkan bahwa motivasi yang diberikan oleh guru di SMAN 3 Batusangkar bertujuan untuk suksesnya proses pembelajaran bahasa Inggris di sekolah tersebut.

Aouta Ghania (2013: 33) juga menyimpulkan bahwa learning style merupakan salah satu faktor untuk mensukseskan pembeajaran bahasa Inggris. Faktor ini merupakan faktor internal, artinya ini berasal dari dalam diri guru maupun siswa. Guru memiliki gaya dalam mengajar secara khas, begitu juga siswa dalam mnengikuti proses pembelajaran memiliki gaya tersendiri sehingga menentukan suksesnya sebuah pembelajaran.

Dalam hal ini learning style yang ada di SMAN 3 Batusangkar di tampilkan melalui upaya guru dalam membangun suasana belajar yang nyaman sehingga memberikan atmosfir yang sejuk bagi siswa dalam proses pembelajaran. Hal ini di mulai guru dengan penggunaan bahasa yang lembut, bahasa yang persuasif yang dicontohkan oleh informan layaknya panggilan lukman al hakim kepada 
anaknya dengan panggilan sayang "Yaa Bunayya". Itulah yang membudaya di SMAN 3 Batusangkar, sehingga dengan pelayanan guru demnikian memberikan kontribusi positif bagi siswa, yang pada akhirnya akan membantu mensukseskan proses pembelajaran di SMAN 3 Batusangkar.

Goleman, Gardner, Hymes dalam D Komang Tantra mengemukakan salah satu faktor kesuksesan pembelajaran bahasa Inggris adalah pada bagian spiritual inteligence yaitu practice (latihan). Dalam hal ini bahasa Inggris SMAN 3 Batusangkar memiliki kegiatan pelatihan-pelatihan yang bertujuan unutk membantu mensukseskan pembelajaran bahasa Inggris. Kegiatan itu berupa homestay yang merupakan kegiatan khas bahasa Inggris SMAN 3 Batusangkar yang berisi praktek-praktek bahasa Inggris berupa kegiatan menulis, speaking, english game, dan penampilan drama bahasa Inggris yang naskahnya ditulis oleh siswa secara mandiri dan pelatihan bahasa Inggris di kampung Inggris Pare, Kediri, Jawa Timur.

Gage dalam Ruty J. Kapoh (2010: 90) mengungkapkan bahwa salah satu yang menentukan kesuksesan pembelajaran bahasa Inggris adalah bakat siswa. Dalam hal ini bahasa Inggris SMAN 3 Batusangkar memiliki kegiatan yang mewadahi siswa dalam mengembangkan bakat siswa dalam kemampuan berbahasa Inggris, yaitu; 1) English Club yang di dalamnya berisi kegiatan berupa speech, debat, drama dan english game. 2) Morning News, dalam kegiatan ini siswa di awal jam pelajaran akan menyampaikan informasi dengan menggunakan bahasa Inggris dengan konten yang di bebaskan kepada siswa untuk memilih. Kedua jenis kegiatan ini didukung penuh oleh sekolah.

\section{PENUTUP}

\section{Kesimpulan}

Dari hasil temuan dan pembahasan yang peneliti paparkan, peneliti meyimpulkan bahwa manajemen pembelajaran bahasa Inggris di SMAN 3 Batusangkar sudah berjalan sesuai dengan aturan yang berlaku. Manajemen pembelajaran bahasa Inggris yang dilakukan di SMAN 3 Batusangkar meliputi dua aspek, yaitu; Aspek Intrakurikuler yang berisi kegiatan perencanaan pembelajaran, penggunaan metode pembelajaran, pelaksanaan pembelajaran dengan mengacu kepada RPP dengan menggunaan metode dan media pembelajaran yang sangat efektif, dan pelaksanaan evaluasi terhadap proses. Aspek Ekstrakurikuler yang dilakukan dalam bentuk memberikan motivasi kepada siswa untuk memiliki kemampuan berbahasa Inggris, membangun hubungan emosional dengan siswa melalui penggunaan bahasa yang lemah lembut kepada siswa, melakukan pelatihan-pelatihan yang bertujuan untuk meningkatkan kemampuan bahasa Inggris siswa melalui kegiatan Homestay dan pelatihan bahasa Inggris ke Kampung Inggris Pare, dan menyalurkan bakat siswa melalui kegiatan English Club dan Morning News. 
Saran

Dari hasil penelitian ini peneliti merekomendasikan kepada;

1. Guru bahasa Inggris SMAN 3 Batusangkar agar lebih berani dan bisa meluangkan waktu untuk mencari dan mencoba menerapkan metode-metode baru yang ditemukan oleh ahli.

2. Guru bahasa Inggris yang berasal dari lembaga yang berbeda untuk melakukan diskusi dan mengadopsi pola-pola yang dilakukan oleh guru SMAN 3 Batusangkar untuk dapat diterapkan di sekolah masing-masing.

3. Sekolah lain untuk mencoba menerapkan pola yang diterapkan SMAN 3 Batusangkar dalam memupuk sinerginitas antara lembaga dan orang tua dalam berbagai aspek. Seperti yang dicontohkan oleh SMAN 3 Batusangkar dalam hal penyerahan hasil belajar siswa yang secara langsung diserahkan kepada orang tua.

4. Peneliti selanjutnya untuk membahas dan menggali lebih dalam yang terkait dengan mata pelajaran bahasa Inggris secara khusus dan manajemen sekolah SMAN 3 Batusangkar secara umum.

\section{KEPUSTAKAAN ACUAN}

Aouta Ghania. 2013. An Analysis ofSome Internal and External Factors Influencing Learners' Success in EFL: The case of third year LMD students at Biskra University. Mohammed Kheidher University of Biskra. Algeira.
Davies, Ivor K. 1991. Manajemen Pembelajaran, Cet Ke-2, Jakarta: Rajawali.

Direktorat Pembinaan SMP. 2012. Panduan Memahami SKL, SK, KD, dan Materi Esensial Mata Pelajaran Bahasa Inggris SMP.

E, Mulyasa. 2002. Manajemen Berbasis Sekolah, 2 Konsep, Strategi, dan Implementasi, cet 1 . Bandung: PT Remaja Rosda Karya.

Elva Ferbriani Utami. 2013. Pengelolaan Pembelajaran Bahasa Inggris (studi perbandingan antara SMPN 1 dan SMPN 14 kota Bengkulu). PPS FKIP Universitas Bengkulu., PDF

Fadlillah, M. 2014. Implementasi Kurikulum 2013 Pada Jenjang SD/MI, SMP/MTs, \& $S M A / M A$, Cet ke-1, Yogyakarta: ArRuzz Media.

Hanaf, Abdul Halim. 2011. Metodologi Penelitian Bahasa. Jakarta: Diadid Media Press.

Mannulang. 1976. Dasar-dasar Mangement, Jakarta: Ghalia.

Moleong, Lexy. 2006. Metodologi Penelitian kualitatif. Cet ke-22. Bandung: PT. Remaja Rosda karya.

Ramayulis. 2002. Ilmu Pendidikan Islam, Jakarta: Kalam Mulia.

Ruty J. Kapoh. 2010. Beberapa Faktor Yang Berpengaruh Dalam Perolehan Bahasa. Interlingua Vol 4, April. 
Permendikbud No. 16 Tahun 2007 Tentang Standar Kualifikasi Akademik Dan Kompetensi Guru

Permendikbud No. 65 Tahun 2013

Permendikbud No. 21 Tahun 2016 Tentang Standar Isi

Tantra D Komang, Teaching English As A Foreign Language In Indonesia: A Literature
Review. Education University of Ganesha Singaraja, Bali. Journal

Sugiyono. 2011. Metode Penelitian Kuantitatif, Kualitatif, dan R\&D. cet ke-12. Bandung: CV. Alfabeta. 